\title{
Availability and consumption of fish as convenience food - correlation between market value and nutritional parameters
}

\author{
Nádia Marion DURAN ${ }^{1}$, Erika da Silva MACIEL ${ }^{2}$, Juliana Antunes GALVÃO ${ }^{1 *}$, Luciana Kimie SAVAY-DA-SILVA ${ }^{3}$, \\ Jaqueline Girnos SONATI ${ }^{4}$, Marília OETTERER ${ }^{1}$
}

\begin{abstract}
Fish consumption is low in Brazil and several factors justify this fact, among them the lack of practicality in preparation. Thus, this study aimed to investigate the relation between the price and the nutritional characteristics of the processed fish products. Correlations between price and nutritional value of 18 different processed fish products were established, comparing nutritional parameters between in natura and processed fish. The results showed that protein features moderate positive correlation to price. The processed fish products analyzed showed lower protein content and higher contents of energy, lipids and sodium compared to in natura fish.
\end{abstract}

Keywords: convenience food; fish consumption; price; nutritional value.

Practical Application: This research has the objective to alert consumers, optimizing the option at the time of purchase, by highlighting the nutritional value as a measure related to the price paid for the product. Is very important development of products with healthiness. Fish is a food that provides this value. The idea is reinforced to obtain new technologies to the consumer market, via processing company, expanding choices and increasing brazilian's fish consumption.

\section{Introduction}

Marine extractive fishing remains as the main source of national fish production, accounting for $42.4 \%$ of total fish production. In 2010, the northeastern region was the largest fish producer in the country, accounting for $32.5 \%$ of the national production, the southern, northern, southeastern and midwestern regions recorded $24.6 \%, 21.7 \%, 14.7 \%$, and $6.6 \%$, respectively (Brasil, 2012).

Increased production and improved distribution channels led to a significant increase of fish supply over the past five decades, with an average growth rate of $3.2 \%$ per year in the period 1961-2009, surpassing 1.7\% of world population growth per year (Food and Agriculture Organization of the United Nations, 2012).

Fish is an important diet component in many countries and contributes to $16.6 \%$ of world consumption of animal protein. The world average per capita consumption is $18.4 \mathrm{~kg}$ of fish per year. However, there is a considerable difference between the per capita values of fish consumption when data is sectored. Consumption amounts to $24.2 \mathrm{~kg}$ of fish per inhabitant per year in developed countries, $28.7 \mathrm{~kg}$ in industrialized countries, $11.1 \mathrm{~kg}$ in countries with economies in transition, $18 \mathrm{~kg}$ in developing countries or areas, and $10.1 \mathrm{~kg}$ in low-income countries (Food and Agriculture Organization of the United Nations, 2012).
In this scenario, Brazil shows one of the lowest average rates of fish consumption per capita per year, $9.75 \mathrm{~kg}$ in 2010 (Brasil, 2012), well below the world average, $18.4 \mathrm{~kg}$ per capita and recommended by FAO (12 kg/inhab/year) (Food and Agriculture Organization of the United Nations, 2009, 2012).

Data from the Household Budget Survey (POF - in Portuguese) 2008-2009 show that Brazilians buys $4 \mathrm{Kg}$ of fish per year. However, the scenario is different when data on fish purchase is analyzed separately for the five regions of the country. People in the northern region buy $17.5 \mathrm{~kg} /$ year while inhabitants of southern and midwestern regions buy $1.6 \mathrm{~kg} /$ year (Instituto Brasileiro de Geografia e Estatística, 2009). The average fish consumption per capita is different from that on fish purchase in Brazil, because POF considers the availability of fish in the households, not the real consumption practiced by individuals (Maciel et al., 2014).

Low fish consumption has been related to problems in the distribution and marketing and, mainly, lack of consumption habit caused in part by the lack of practicality in fish preparation. In addition, fish consumption is subject to the purchasing power of consumers and availability fish with suitable quality (Trondsen et al., 2003; Maciel et al., 2013).

${ }^{1}$ Departamento de Agroindústria, Alimentos e Nutrição, Escola Superior de Agricultura "Luiz de Queiroz" - ESALQ, Universidade de São Paulo - USP, Piracicaba, SP, Brazil ${ }^{2}$ Centro Universitário Luterano de Palmas CEULP - ULBRA, Palmas, TO, Brazil

${ }^{3}$ Departamento de Alimentos e Nutrição, Faculdade de Nutrição, Universidade Federal de Mato Grosso - UFMT, Cuiabá, MT, Brazil

${ }^{4}$ Departamento de Enfermagem e Nutrição, Universidade de Taubaté - UNITAU, Taubaté, SP, Brazil

*Corresponding author: jugalvao@usp.br 
Therefore, there is the need to bring to the market alternatives to fish consumption. Among these, convenience products are a trend in current market.

A study of the Federation of Industries of the State of São Paulo (FIESP) and the Institute of Food Technology (ITAL) (Federação das Indústrias do Estado de São Paulo \& Instituto de Tecnologia de Alimentos, 2010) showed the main trends of food market for the coming years. "Convenience and practicality", proportionally, account for the largest share regarding fish consumption in the country, comprising $34 \%$ of Brazilian food consumers from social classes A, B and C. The Brazilian's priority for "convenience and practicality" is mainly attributed to the new lifestyle of the population, which includes little time to prepare meals. The importance of convenience or processed fish products is therefore highlighted, which in addition to "convenience and practicality", they also represent "healthiness and well-being" due to their nutritional value.

The preference for convenience foods is justified because they are more practical to prepare, suggesting a change in the paradigm of industrial scale production with a new configuration in processing food products (Ruiz \& Gonçalves, 2011).

The industrial processing of fish products allows a thorough use of fish, including species with low-commercial value. Fish processing extends shelf life, adds value, and increases consumption, besides generating jobs and income for the population. Therefore, research in the field of fish technology is necessary to develop fish products primarily for human consumption such as fishburger, nuggets, sausages, surimi, among others (Marengoni et al., 2009).

In view of the low fish consumption in Brazil and the current trend of the food market for convenience, practicality and healthiness, this study aimed to investigate the relation between the price and the nutritional characteristics of the processed fish products.

\section{Materials and methods}

Prices of 18 convenience fish products were collected. The data were obtained in the retail market, in 28 supermarkets, in 21 cities around the country. For products belonging to the same category and brand, the average price was considered due to price differences between cities.

The nutritional value of fish species marketed in natura, namely hake, tilapia, pintado (spotted sorubim), tambaqui, shrimp and salmon was evaluated comparatively with the nutritional value of processed fish available in the market with a basis of these species.

For in natura species, five variables were considered for the nutritional value (proteins, energy, saturated fat, total fat and sodium) available in the Brazilian Table of Food Composition of UNICAMP (Universidade Estadual de Campinas, 2011) and the Brazilian Table of Food Composition of USP (Universidade de São Paulo, 1998). Nutritional information of processed fish products was obtained on the product packaging.

Data were analyzed through a quantitative description. The descriptive analysis included calculations of proportions and $95 \%$ confidence intervals.
Data normality was tested and the Spearman correlation test was applied to check possible associations between variables, price and nutritional value of the product. The statistical program SPSS was used and the significance level $\mathrm{p}<0.05$ was considered.

A description of nutritional value was made of the processed fish product and the equivalent in natura and between the price and the nutritional value.

\section{Results and discussion}

The price range for the 18 varieties of processed fish products proved to be wide and diverse. The values ranged from US\$3.03/kg for fish steak to US\$39.08/kg for sliced smoked salmon. The average was US\$14.22 ( \pm US\$11.30) the period of data collection.

The nutritional value of processed fish products showed heterogeneity. The average values (in $100 \mathrm{~g}$ ) for energy were $172.55 \mathrm{kcal}( \pm 54.71)$, protein $14.05 \mathrm{~g}( \pm 4.90)$, total fat $7.45 \mathrm{~g}$ $( \pm 4.52)$, saturated fat $2.29 \mathrm{~g}( \pm 1.99)$ and sodium $414.5 \mathrm{mg}( \pm 272.8)$.

The correlation analysis between price and nutrients registered on the product label indicates significant correlations with statistical significance (Table 1).

There was positive significant correlation (Levin \& Fox, 2004) between price and protein, as well as price and sodium. Thus, as the product price increases, the protein and sodium contents in the product also increase.

There was also significant positive correlation, as expected, between energy and total fat, energy and saturated fat, as well as total fat and saturated fat. This relationship shows that these items are associated with each other and as the fat content increases, the energy contents also increase in the product.

The nutrients in processed fish products were compared to the source in natura fish and the results are described in Table 2.

The energy value of processed products can reach $376.5 \%$ compared to in natura fish, for instance, shrimp nuggets. The increased amounts of calories in western diet is attributed among other factors to innovation processes before food industrialization (Bleil, 1998).

The incorporation of other ingredients to the main raw material, such as flour and fat, are responsible for the energy supply of lipid of these products. In addition, nuggets are usually pre-fried before freezing, which also contributes to this increase. Considering that this preparation procedure is also used in households in Brazil, this increase of energy supply should not be attributed solely to industrialization.

Table 1. Spearman correlation between price and nutrients in processed fish products.

\begin{tabular}{ll}
\hline \multicolumn{1}{c}{ Spearman correlation } & $\mathrm{r}$ \\
\hline Price x Protein & $0.500^{*}$ \\
Price x Sodium & $0.552^{*}$ \\
Energy x Total fat & $0.874^{\star *}$ \\
Energy x Saturated fat & $0.850^{* *}$ \\
Total fat x Saturated fat & $0.860^{* *}$ \\
\hline
\end{tabular}

${ }^{*}$ Correlation is significant at $0.05 \% ;{ }^{* *}$ Correlation is significant at $0.01 \%$ 
Table 2. Nutrients of in natura and processed fish products.

\begin{tabular}{|c|c|c|c|c|c|c|}
\hline \multirow{2}{*}{ Product $(100 \mathrm{~g})$} & \multicolumn{2}{|c|}{ Energy } & \multirow{2}{*}{$\begin{array}{c}\text { Protein } \\
(\mathrm{g} / 100 \mathrm{~g})\end{array}$} & \multicolumn{2}{|c|}{ Fats $(g / 100 g)$} & \multirow{2}{*}{$\begin{array}{c}\text { Sodium } \\
(\mathrm{mg} / 100 \mathrm{~g}) \\
\end{array}$} \\
\hline & (kcal) & $(\mathbf{k j})$ & & Total & Saturated & \\
\hline Hake fillet in natura & 89 & 373 & 16.6 & 2 & 0.9 & 80 \\
\hline Hake nuggets & 174 & 727 & 12 & 6.7 & 0.8 & 263 \\
\hline Tilapia fillet in natura & 72 & 301 & 16.15 & 0.19 & - & 35 \\
\hline Strip nuggets of tilapia & 234 & 982 & 13 & 11 & 2.8 & 533 \\
\hline Pintado in natura & 91 & 381 & 18.6 & 1.3 & 0.6 & 43 \\
\hline Pintado fillet nuggets & 236 & 991 & 15 & 12 & 3.2 & 488 \\
\hline Tambaqui fillet in natura & 151 & 633 & 24.8 & 5.8 & - & 76 \\
\hline Tambaqui nuggets & 250 & 1050 & 14 & 13 & 3.7 & 456 \\
\hline Tambaqui hamburger & 240 & 1008 & 12 & 12 & 3.2 & 353 \\
\hline Shrimp in natura & 47 & 197 & 10 & 0.5 & 0.1 & 201 \\
\hline Shrimp nuggets & 177 & 744 & 8 & 8 & 2.5 & 542 \\
\hline Skinless salmon fillets in natura & 170 & 710 & 19.3 & 9.7 & 2.5 & 64 \\
\hline Sliced smoked salmon & 233 & 976 & 20 & 17 & 6 & 739 \\
\hline Smoked salmon pâté & 200 & 838 & 6 & 16 & 0 & 1090 \\
\hline
\end{tabular}

The protein reduction that occurred due to incorporation in the calorific components to the product could be intensified in Mechanically Separated Meat (MSM) products (nuggets, fishburgers) because the washing process necessary to obtain these products removes soluble proteins (Grantham, 1981). The literature reports decrease in protein content of approximately $53 \%$ during the washing process of hake (Cynoscion striatus) nuggets (Simões et al., 1998).

According to Brazilian law, food nuggets must present values equal to or greater than $10 \%$ for protein in their compositions (Brasil, 2001). In the data survey of this study, one product, shrimp nuggets, presented $8 \%$ of protein, showing non-conformity.

The increase of lipids and, consequently, of kilocalories is greater when product is fried by immersion in oil. In cooking, lipids are known to enhance flavor and satiety sensation, however, the most appreciated attributes are favoring aroma and texture of foods (Salinas, 2002).

The acceptance of food preparation through frying is universal and appreciation is observed in different population groups (Perkins \& Erickson, 1996). Frying is used in households, however, mostly commonly adopted in restaurants where it is considered advantageous due to the need for agility in services (Ans et al., 1999; Cella et al., 2002).

Currently, there is strong concern on the part of the population in general with healthfulness of foods consumed. Therefore, more and more the frying process is replaced for other cooking methods (Brasil, 2014). Processed fish products suggesting the use of baking in replacement of frying are described in the scientific literature. Baked tilapia quenelles showed good sensory acceptance, emphasizing the feasibility of this cooking method. In addition, as it is not buttered and pre-fired, the quenelles presented only 147 kilocalories and $7.1 \mathrm{~g}$ of total fats in $100 \mathrm{~g}$, significantly below the values observed for the commercial product, tilapia strip nuggets (Angelini et al., 2013).

A concern of many processed products in general, as well as processed fish products analyzed in this study, is the significant sodium content, whose excess intake is associated with the development of hypertension, cardiovascular and kidney diseases, the main causes of hospitalizations and deaths in Brazil and in the world (Sarno et al., 2009).

In this study, in relation to in natura fish, the increase in sodium content is $169.6 \%$ shrimp nuggets, reaching $1,063 \%$ for smoked salmon pâté. It should be highlighted that fish is never consumed without any seasoning in households. The World Health Organization (WHO) recommends a maximum consumption of $2000 \mathrm{mg}$ (2 grams) of sodium a day, which is equivalent to $5 \mathrm{~g}$ of salt, however, Brazilians currently consume more than twice this amount (Instituto Brasileiro de Geografia e Estatística, 2009).

With the focus on healthiness, strong tendency of the food market, food processors need to invest in alternatives to reduce the concentration of sodium chloride in their products.

Several salts give foods a salty taste, such as potassium chloride. However, most of these salts show a characteristic residual flavor, which hinders their acceptance (Sahoo et al., 2004). The use of taste enhancers contribute to the reduction of this residual taste and mask the perception of reduced sodium chloride, for example, yeast extracts, lactates, and nucleotides (Pérez-Alvarez et al., 2010).

The inclusion of fish into the food service segment is increasingly incisive and government programs encourage such inclusion, for example, the project "Promotion of Fish Consumption at School Lunch" created by the Ministry of Fisheries and Aquaculture (MPA) in conjunction with the National Education Development Fund (Fundo Nacional do Desenvolvimento da Educação, 2010).

Assessment on consumption of eight groups of processed foods in the city of São Paulo showed that the sausages, burgers and nuggets take the third place in the ranking of most consumed products (Barros, 2008). This shows the need to encourage consumption of these fish-based products, as well as investment by industry in promoting these products on the market. 
This trend has reinforced the fact that consumers nowadays are increasingly willing to buy minimally processed foods. Thus, for fish products it is no different, since the product in natura requires time and skill for cutting and cleaning. About $70 \%$ of the tilapias produced in São Paulo, for example, is offered in supermarkets in fillets (Sussel, 2011).

There is also the viable proposal for a package with modified atmosphere, which can be closed after use allowing the consumer to remove only the quantity needed for each meal (Fitzsimmons et al., 2009).

Clearly, although buttered and fried product pleases the consumer sensorially, consumers demand foods that provide healthiness and well-being, a current and strong market trend for years to come (Federação das Indústrias do Estado de São Paulo \& Instituto de Tecnologia de Alimentos, 2010). The food industry needs to follow this trend and invest in the creation of ready meals and other products that meet this demand.

\section{Conclusion}

In general, there is no variety of these products on display as well as prices compatible with the quality of the products offered.

There is a positive and statistically significant association between protein content in convenience products and their prices, which suggests a high nutritional quality and cost/benefit advantage for purchase.

The products studied showed contents sodium and energy higher than conventional products and the original raw material. This occurs because of the addition of other ingredients and, or the proposed product preparation, which may affect product healthiness.

The product price is greater as the sodium content increases, which disqualifies the cost/benefit of processed fish products. However, the use of salt in Brazilian cuisine is the determining factor in sodium intake for the population that should be considered. In case of salt intake, its control should not be limited to only removing industrialized foods from the diets.

Research on fish processing allows the development of products with lower lipid and sodium contents, ensuring sensory quality and that can be adopted by food processors to place convenience foods within the categories "healthiness and well-being" and offer "convenience and practicality".

\section{References}

Angelini, M. F. C., Galvão, J. A., Vieira, A. F., Savay-da-Silva, L. K.; Shirahigue, L. D.; Cabral, I. S. R., Modesta, R. C. D., Gallo, C. R., \& Oetterer, M. (2013). Vida útil e avaliação sensorial de quenelle de tilápia durante o armazenamento em freezer. Revista Pesquisa Agropecuária Brasileira, 48(8), 1080-1087.

Ans, V. G., Mattos, E. S., \& Jorge, N. (1999). Avaliação da qualidade dos óleos de fritura usados em restaurantes, lanchonetes e similares. Ciência, Tecnologia e Alimentação, 19, p. 413-419. http://dx.doi. org/10.1590/S0101-20611999000300021.

Barros, R. R. (2008). Consumo de alimentos industrializados e fatores associados em adultos e idosos residentes no município de São Paulo
(Dissertação de mestrado). Faculdade de Saúde Pública, Universidade de São Paulo, São Paulo.

Bleil, S. I. (1998). O padrão alimentar ocidental: considerações sobre a mudança de hábitos no Brasil. Cadernos de Debate., 1, 1-25.

Brasil. Ministério da Agricultura e do Abastecimento. (2001, February 19). Instrução normativa ${ }^{\circ} 06$, de 15 de fevereiro de 2001. Aprova os regulamentos técnicos de identidade e qualidade de paleta cozida, produtos cárneos salgados, empanados, presunto tipo serrano e prato elaborado pronto ou semipronto contendo produtos de origem animal. Diário Oficial [da] República Federativa do Brasil, seção 1.

Brasil. Ministério da Pesca e Aquicultura. (2012). Boletim Estatístico da Pesca e Aqüicultura - Brasil 2010 (128 p.). Brasília: Ministério da Pesca e Aquicultura. Retrieved from http://www.mpa.gov.br/images/Docs/ Informacoes_e_Estatisticas/Boletim\%20Estat\%C3\%ADstico\%20 MPA\%202010.pdf

Brasil. Ministério da Saúde. Secretaria de Atenção à Saúde. Departamento de Atenção Básica. (2014). Guia alimentar para a população brasileira (2 ed., 156 p.). Brasília: Ministério da Saúde.

Cella, R. C. F., Regitano-D’Arce, M. A. B., \& Spoto, M. H. F. (2002). Comportamento do óleo de soja refinado utilizado em fritura por imersão com alimentos de origem vegetal. Ciência e Tecnologia de Alimentos, 22, 111-116.

Federação das Indústrias do Estado de São Paulo - FIESP, \& Instituto de Tecnologia de Alimentos - ITAL. (2010). Brasil Food Trends 2020 (173 p.). São Paulo: Gráfica Ideal. Retrieved from http://www. brasilfoodtrends.com.br/Brasil_Food_Trends/index.html

Fitzsimmons, K., Alghanim, K., \& Naim, S. (2009). Tilapia production, market report. Global Aquaculture Advocate Magazine, sept/oct. 67-70.

Food and Agriculture Organization of the United Nations - FAO. (2009). The state of world fisheries and aquaculture 2008 (176 p.). Rome: FAO.

Food and Agriculture Organization of the United Nations - FAO. (2012). The state of world fisheries and aquaculture 2012 (176 p.). Rome: FAO.

Fundo Nacional do Desenvolvimento da Educação - FNDE. (2010). Projeto promoção do pescado na alimentação escolar. Retrieved from http://www.fnde.gov.br/arquivos/category/116-alimentacao escolar?download $=5216$ :poliana-sperandio-mpa-17112010

Grantham, G. J. (1981). Minced fish technology: a review (No. 216, 41 p.). Roma: FAO.

Instituto Brasileiro de Geografia e Estatística - IBGE. (2009). Pesquisa de Orçamento Familiar: 2008-2009. Rio de Janeiro: IBGE. Retrieved from http://www.ibge.gov.br/home/estatistica/populacao/condicaodevida/ pof/2008_2009_analise_consumo/pofanalise_2008_2009.pdf

Levin, J., \& Fox, J. A. (2004). Estatística para ciências humanas (497 p.). São Paulo: Prentice Hall.

Maciel, E. S., Savay-da-Silva, L. K., Galvão, J. A., Vieira, A. F., Sonati, J. G., Lima, L. K. F., \& Oetterer, M. (2014). Availability of fish in Brazilian households: analysis of data from the 2008-2009 survey of family budgets. International Journal of Applied, 4(4), 102-110.

Maciel, E. S., Savay-da-Silva, L. K., Vasconcelos, J. S., Sonati, J. G., Galvão, J. A., Lima, L. K. F., \& Oetterer, M. (2013). Relationship between the price of fish and its quality attributes: a study within a community at the University of São Paulo, Brazil. Food Science and Technology, 33(3), 451-456.

Marengoni, N. G., Pozza, M. S. S., Braga, G. C., Lazzeri, D. B., Castilha, L. D., Bueno, G. W., Pasquetti, T. J., \& Polese, C. (2009). Caracterização microbiológica, sensorial e centesimal de fishburgers de carne de tilápia mecanicamente separada. Revista Brasileira de Saúde e Produção Animal, 10(1), 168-176.

Pérez-Alvarez, J. A., Sendra-Nadal, E. \& Sánchez-Zapata, E. J. (2010). Poultry flavor: general aspects and applications. In I. Guerrero- 
Legarreta (Ed.), Handbook of poultry science and technology (chap. 8, pp. 81-88). New Jersey: John Wiley \& Sons.

Perkins, E. G., \& Erickson, M. D. (1996). Deep frying, chemistry, nutrition and practical applications (357 p.). Champaign: AOCS Press.

Ruiz, W. A., \& Gonçalves, A. A. (2011). Vida de prateleira do pescado. In A. A. Gonçalves. Tecnologia do pescado: ciência, tecnologia, inovação e legislação (cap. 3, pp. 338-359). São Paulo: Editora Atheneu.

Sahoo, J., Sajala, K. S. S., \& Kumar, M. (2004). Low salt meat products as health food. Natural Product Radiance, 3(4), 309-318.

Salinas, R. D. (2002). Alimentos e nutrição: introdução a bromatologia (3 ed., 278 p.). Porto Alegre: ARTMED.

Sarno, F., Claro, R. M., Levy, R. B., Bandoni, D. H., Ferreira, S. R. G., \& Monteiro, C. A. (2009). Estimativa de consumo de sódio pela população brasileira, 2002-2003. Revista de Saúde Pública, 43(2), 219-225.
Simões, D. R. S., Pedroso, M. A., Ruiz, W. A., \& Almeida, T. L. (1998). Hambúrgueres formulados com base protéica de pescado. Ciência e Tecnologia de Alimentos, 18(4), 414-420. http://dx.doi.org/10.1590/ S0101-20611998000400011.

Sussel, F. R. (2011). Criação de tilápias cresce vigorosamente no Brasil. Retrieved from ftp://ftp.sp.gov.br/ftppesca/Tilapia_2011.pdf

Trondsen, T., Scholderer, J., Lund, E., \& Eggen, A. E. (2003). Perceived barriers to consumption of fish among Norwegian women. Research in Reproduction, 41, 301-314.

Universidade de São Paulo - USP. (1998). Tabela Brasileira de Composição de Alimentos - TBCA (Versão 5.0). São Paulo: USP/ BRASILFOODS.

Universidade Estadual de Campinas - UNICAMP. (2011). Tabela Brasileira de Composição de Alimentos - TACO (Versão 3. 3 ed.). Campinas: UNICAMP/NEPA. 